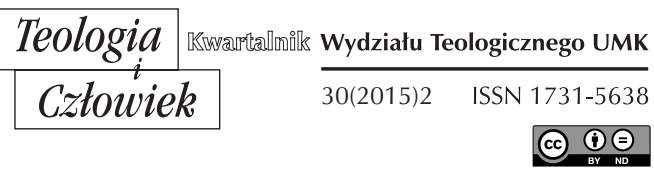

KS. PIOTR WIŚNIEWSKI*

LUBLIN

\title{
MONODIA ŁACIŃSKA W XLI EDYCJI ŚPIEWNIKA KOŚCIELNEGO KS. JANA SIEDLECKIEGO
}

DOI: http://dx.doi.org/10.12775/TiCz.2015.024

W oficynie wydawniczej Instytutu Teologicznego Księży Misjonarzy w Krakowie ukazało się w 2015 roku kolejne już, XLI wydanie Śpiewnika kościelnego ks. Jana Siedleckiego, pod redakcją ks. Wojciecha Kałamarza CM (redaktora naczelnego) i ks. Andrzeja Ziółkowskiego CM, wpisujące się w panoramę dziejów Kościoła i jego liturgii. Truizmem byłoby przypominanie na nowo jego genezy ${ }^{1}$ i znaczenia. Niemniej jed-

* Piotr Wiśniewski - dr hab. nauk humanistycznych w zakresie historii muzykologii, kierownik Katedry Polifonii Religijnej Instytutu Muzykologii KUL. Należy do: Towarzystwa Naukowego KUL, Stowarzyszenia Polskich Muzyków Kościelnych, Towarzystwa Naukowego Franciszka Salezego, Associazione Internazionale Studi di Canto Gregoriano (Deutschsprachige Sektion). W badaniach naukowych podejmuje zagadnienia związane z postgregoriańską monodią liturgiczną w Polsce w rękopiśmiennych i drukowanych kodeksach muzyczno-liturgicznych oraz wybrane problemy współczesnej polskiej muzyki kościelnej.

1 Zob. R. Gradzik, Dzieje „Śpiewnika kościelnego” księdza Jana Siedleckiego w latach 1876-1929, Lublin 1980 (mps pracy magist. w Arch. KUL); S. Grenda, Dzieje Śpiewnika kościelnego ks. Jana Siedleckiego, Lublin 1983 (mps pracy magist. w Arch. KUL); J. Kwiatkowski, Śpiewnik kościelny ks. Jana Siedleckiego jako przekaz śpiewów liturgicznych, Warszawa 2011 (mps pracy lic. w Bibl. UKSW). 
nak warto podkreślić, iż śpiewnik ten, wydawany nieprzerwanie od 1876 roku, jest zbiorem wielce zasłużonym dla kultury muzycznej Kościoła w Polsce. Aktualną jego edycję, znacznie wzbogaconą o nowy repertuar liturgiczny, należy powitać z ogromną radością także z tego powodu, iż ciągle odczuwa się deficyt dobrych śpiewników służących liturgii ${ }^{2}$. Należy zaznaczyć także, że Śpiewnik kościelny ks. Siedleckiego jest najbardziej rozpowszechnionym zbiorem pieśni w Polsce, który zyskał na przestrzeni 136 lat charakter ogólnopolski. Można więc z całym przekonaniem stwierdzić, że księga ta jest kontynuatorem dotychczasowych modlitewników i śpiewników kształtujących pobożność i życie religijne ludu Bożego. Celem podjętego studium nie jest szczegółowe i wyczerpujące omówienie zawartości całego zbioru pod względem formalnym i merytorycznym ${ }^{3}$, ale zwrócenie uwagi wyłącznie na śpiewy gregoriańskie. Dokumenty Kościoła (Konstytucja o Liturgii św., nr 116; Instrukcja Musicam sacram, rozdz. VI) w sposób jednoznaczny wskazują bowiem miejsce chorału gregoriańskiego w posoborowej liturgii, określając go śpiewem własnym (cantus proprius) liturgii rzymskiej. Jak trafnie zauważa Franz Karl Prassl, obecność dzisiaj tego śpiewu w liturgii nie jest żadnym argumentem historycznym, tylko liturgiczno-teologicznym. Śpiew gregoriański jest bowiem „retorycznie ukształtowaną kompozycją z tekstów Pisma Świętego przy pomocy muzycznych środków”; stoi w służbie Słowa i „jest śpiewaną interpretacją Biblii w liturgii”. Chorał gregoriański jest przeto pierwszą europejską, autentyczną muzyką liturgii ${ }^{4}$.

${ }^{2}$ W 2012 roku na zjeździe Stowarzyszenia Polskich Muzyków Kościelnych w Białymstoku została sformułowana kolejna wyraźna potrzeba nowej edycji Śpiewnika liturgicznego dla Kościoła w Polsce, zob. G. Poźniak, Kilka uwag wstępnych na temat projektu nowego Śpiewnika liturgicznego, „Musica Ecclesiastica” 10(2015), s. 113. Obecny tego rodzaju zbiór wymaga już bowiem rewizji.

${ }^{3} \mathrm{Na}$ ten temat zob. W. Kałamarz, Doświadczenia $w$ redakcji XLI wydania Śpiewnika kościelnego ks. Jana Siedleckiego, „Musica Ecclesiastica” 10(2015), s. 115-124.

${ }^{4}$ „Der gregorianische Gesang ist rhetorisch gestaltete Komposition von Texten der Hailigen Schrift mit musikalischen Mitteln”, „... ist gesungene Interpretation der Bibel in der Liturgie”, F.K. Prassl, Gregorianik im Gotteslob 2013, „Beiträge zur Gregorianik” 2014 , t. 57 , s. 53. 
Chcemy w związku z tym odpowiedzieć na pytanie, w jakim stopniu dowartościowano klasyczną monodię łacińską w świetle obowiązujących przepisów liturgicznych oraz na ile skorzystano ze skarbca muzyki gregoriańskiej w przygotowaniu nowego wydania Śpiewnika kościelnego. Na podobne pytania autor niniejszego opracowania starał się odpowiedzieć, analizując nowe wydanie niemieckiego śpiewnika Gotteslob $(2013)^{5}$. W toku prowadzonych badań nad interesującym nas repertuarem zawartym w edycji ks. Siedleckiego będziemy zatem przywoływali dla porównania uzyskane wyniki studiów nad zbiorem niemieckim. Tym samym możliwe będzie stwierdzenie, który z ostatnio wydanych śpiewników bardziej otworzył się na muzyczny skarbiec Kościoła.

\section{EPERTUAR ŚPIEWÓW GREGORIAŃSKICH}

Śpiewy łacińskie w Śpiewniku kościelnym zostały zebrane w osobnym dziale i ułożone według poszczególnych okresów roku liturgicznego $\mathrm{w}$ trzech mniejszych poddziałach. Wynotujemy je kolejno, z wyjątkiem utworów pseudogregoriańskich, zgodnie ze schematem przyjętym w edycji:

I. Śpiewy wybrane

W okresie Adwentu:

- Creator alme siderum

- Ecce Dominus veniet

W okresie Narodzenia Pańskiego:

- Puer natus in Betlehem

Ku czci Najświętszego Imienia Jezus - 3 stycznia:

- Iesu, dulcis memoria

W okresie Wielkiego Postu:

- Attende Domine, et miserere

- Miserere mei Deus

- Parce Domine

- Stabat Mater

${ }^{5}$ P. Wiśniewski, Repertuar gregoriański w nowym wydaniu (2013) niemieckiego śpiewnika liturgicznego „Gotteslob”, w: W. Hudek, P. Wiśniewski (red.), Cantare amantis est. Wieloautorska monografia naukowa z okazji 80. urodzin Ks. Prof. dr. hab. Ireneusza Pawlaka, Lublin 2015, s. 350 i n. 
- Ubi caritas est vera

W okresie wielkanocnym:

- Regina caeli laetare, alleluia

- Victimae paschali laudes

Do Ducha Świętego:

- Veni Creator

- Veni, Sancte Spiritus

Ku czci Najświętszego Sakramentu:

- Adoremus in aeternum

- Adoro te devote

- Ave verum Corpus natum

- Lauda, Sion

- O salutaris Hostia

- Tantum ergo sacramentum

Ku czci najświętszej Maryi Panny:

- Alma Redemptoris Mater

- Ave Maria

- Ave, maris stella

- Ave, Regina caelorum

- Salve, Regina

Śpiewy za zmarłych:

- Dies irae

- In paradisum

- Lux aeterena

- Requiem aeternam

II. Cykle mszalne

- Missa „Primitiva”

- Missa VIII De Angelis

- Missa XI Orbis factor

- Credo III

Na pokropienie wodą święconą $\mathrm{w}$ niedziele:

- Asperges me, Domine

- Vidi aquam egredientem

$\mathrm{Na}$ dziękczynienie:

- Te Deum laudamus

III. Tony psalmowe

- Primus Tonus

- Secundus Tonus 
- Tertius Tonus

- Quartus Tonus

- Quintus Tonus

- Sextus Tonus

- Septimus Tonus

- Octavus Tonus

- Tonus Peregrinus.

Ogółem wszystkie śpiewy łacińskie, łącznie z tonami psalmowymi (9), składają się na pokaźny repertuar liturgiczny w liczbie 44 kompozycji. Jest to radykalna różnica w stosunku do wcześniejszego, XL wydania tego śpiewnika, gdzie wydrukowano ich, także z tonami psalmowymi (9), tylko 24. W nowej edycji mamy zatem do czynienia ze znaczącym poszerzeniem skarbca twórczości gregoriańskiej, będącej bardzo ważnym elementem szerokiego zakresu muzyki liturgicznej.

\section{ANALIZA ZAWARTOŚCI}

Jak słusznie zaznaczono w słowie wstępnym do tego działu pieśni, znajdują się w tej grupie klasyczne kompozycje gregoriańskie, śpiewy w stylu gregoriańskim oraz inne utwory w języku łacińskim ${ }^{6}$. Oznacza to, że mamy do czynienia nie tylko $\mathrm{z}$ chorałem gregoriańskim w sensie ścisłym ${ }^{7}$, ale także $\mathrm{z}$ utworami pseudogregoriańskimi. Wydrukowany w zbiorze ks. Siedleckiego interesujący nas wyłącznie repertuar gregoriański rozpatrzymy kolejno według gatunków muzycznych.

${ }^{6}$ Ks. Jan Siedlecki. Śpiewnik kościelny, Wydanie XLI, s. 1031.

7 Klasyczny chorał gregoriański ukształtował się zasadniczo w VIII wieku. Szybko okazało się jednak, że ten ukształtowany w epoce karolińskiej repertuar nie na długo zadowolił ówczesnego uczestnika liturgii. Powołano więc do istnienia nowe, nieznane dotychczas formy monodii liturgicznej: tropy, wersety allelujatyczne, śpiewy ordinarium missae i inne. Te nowo powstałe w IX wieku śpiewy, dla odróżnienia ich od form klasycznych, nazwano postgregoriańskimi, szerzej zob. P. Wiśniewski, Śpiewy późnośredniowieczne w antyfonarzach płockich $z$ XV/XVI wieku na podstawie responsoriów Matutinum, Lublin 2010, s. 16. 


\section{1. ŚPIEWY MSZALNE}

\subsubsection{ORDINARIUM MISSAE}

W interesującym nas śpiewniku umieszczono zarówno śpiewy ordinarium, jak i proprium missae. Obecnie pod nazwą ordinarium missae rozumie się nie tylko pięć części cyklu mszalnego (Kyrie, Gloria, Credo, Sanctus, Agnus Dei), ale także inne mszalne śpiewy stałe: Pater noster, dialogi i aklamacje oraz śpiewy na pokropienie przed sumą ${ }^{8}$. W tradycyjnym repertuarze gregoriańskim istnieje ogółem osiemnaście numerowanych, pełnych cykli mszalnych ${ }^{9}$ o zróżnicowanym przeznaczeniu (na okres Wielkanocny, Narodzenia Pańskiego, niedziele w ciągu roku itd.).

2.1.1.1. CYKLE MSZALNE

W najnowszym wydaniu Śpiewnika kościelnego ks. Siedleckiego nie zrezygnowano z cyklów mszalnych, co było wyraźnym założeniem Ogólnego Wprowadzenia do Mszału Rzymskiego z 1975 roku, zalecającym, aby Kyrie i Agnus Dei miały formę litanii, Gloria było hymnem, a Sanctus aklamacją (nn. 30, 31, 54b, 56e $)^{10}$. Najprawdopodobniej redaktorzy wydania nie wzięli pod uwagę tych wskazań, jak również racji historycznych,

${ }^{8}$ I. Pawlak, Muzyka liturgiczna po Soborze Watykańskim II w świetle dokumentów Kościoła, Lublin 2000, s. 138-139, 146.

${ }^{9}$ Formowanie się poszczególnych śpiewów tej grupy w tzw. cykle nastąpiło przypuszczalnie dopiero w XII wieku. Częściej jednak zapisywano razem tylko Kyrie i Gloria, natomiast Agnus Dei i Sanctus grupowano oddzielnie. Dopiero w późnym średniowieczu, na zasadzie podobieństwa melodii poszczególnych śpiewów, zaczęto łączyć poszczególne części w cykle. Pierwsza próba ujednolicenia pod względem motywicznym części stałych ( $\mathrm{z}$ wyjątkiem Credo) nastąpiła w benedyktyńskim klasztorze na terenie Bawarii, zob. E. Ryżowicz, Msze jednogłosowe w języku polskim po Soborze Watykańskim II, Lublin 1984, s. 21-22 (mps pracy magist. w Arch. KUL).

${ }^{10}$ I. Pawlak, XX-wieczne pieśni w Śpiewniku Liturgicznym i ich inspiracje, w: S. Garnczarski (red.), Ks. Ireneusz Pawlak, De musica sacra in Polonia. Questiones selectae, t. 1, Tarnów 2013, s. 296; por. Z. Piasecki, Śpiewy Ordinarium Missae w języku polskim, w: J. Pikulik (red.), Stan badań nad muzyka religijna $w$ kulturze polskiej, Warszawa 1973, s. 254. 
a jedynie skopiowali gotowe schematy z Kyriale ${ }^{11}$. Warto nadmienić, iż w identyczny sposób postąpiono w śpiewniku Gotteslob ${ }^{12}$. Śpiewnik ks. Siedleckiego drukuje trzy wybrane cykle mszalne: Mszę VIII, XI i tzw. Mszę krótką (Missa Primitiva), złożoną z Kyrie z Mszy XVI, Gloria z Mszy XV, Sanctus i Agnus Dei z Mszy XVIII ${ }^{13}$.

Do części stałych mszy zalicza się także credo, chociaż stanowi ono kompozycję samodzielną, niewykazującą związków z pozostałymi śpiewami ordinarium missae ${ }^{14}$. Spośród jego sześciu wersji melodycznych zamieszczonych w Liber Usualis ${ }^{15}$ dwie najpopularniejsze (Credo I i Credo III) znalazły się w śpiewnikach posoborowych. Edycja ks. Siedleckiego, podobnie jak inne śpiewniki polskie ${ }^{16}$, ale nie tylko (np. Gotteslob), posługuje się melodią Credo III, co świadczy o dużej popularności tej kompozycji.

${ }^{11}$ Cykl mszalny zawarty w obecnym Kyriale kształtował się począwszy od wczesnego średniowiecza aż do XVIII wieku. Poszczególne śpiewy ordinarium missae pochodzą z różnych okresów i pojawiły się najprawdopodobniej w następującym porządku: Sanctus, Kyrie, Gloria, Agnus Dei i Credo. Najprostsze ich melodie sięgają początków średniowiecza, kiedy to ordinarium śpiewał lud. Dopiero z chwilą wykształcenia się notacji muzycznej zaczęły powstawać pierwsze ich zapisy, które utworzyły w późnym średniowieczu, na zasadzie podobieństwa lub identyczności melodii poszczególnych części, cykl mszalny, szerzej zob. E. Ryżowicz, Msze jednogłosowe, s. 20 i n.

12 P. Wiśniewski, Repertuar gregoriański, s. 354.

${ }_{13}$ Missa primitiva została utworzona w Kyriale simplex z 1964 roku dla użytku mniejszych kościołów. Instrukcje zawarte we wstępie Kyriale simplex informują o możliwości dowolnego łączenia pojedynczych części z różnych schematów. Jest to nawiązaniem do tradycji, kiedy to umieszczano wszystkie części ordinarium oddzielnie, por. K. Lisman, Repertuar gregoriański w polskich śpiewnikach katolickich po Soborze Watykańskim II, Lublin 2001, s. 61 (mps pracy magist. w Arch. KUL).

${ }^{14}$ K.H. Schlager, Credo, w: L. Finscher (red.), Die Musik in Geschichte und Gegenwart, Kassel 1994-1998, t. 2, kol. 1039.

${ }^{15}$ Liber Usualis. Missae et Officii, Parisiis-Tornaci-Romae-Neo Eboraci 1958, s. $64-78$.

16 S. Garnczarski, Chorat gregoriański zawarty w polskich śpiewnikach katolickich XIX i XX wieku, „Tarnowskie Studia Teologiczne” 22(2003), t. 2, s. 98. 


\subsubsection{3. ŚPIEWY NA POKROPIENIE}

Do grupy ordinarium missae należą także zamieszczone w nowej edycji śpiewnika dwie antyfony w czasie niedzielnego pokropienia przed sumą: Asperges me i Vidi aquam. Pierwszą z nich, Asperges me (wykonywaną poza okresem wielkanocnym), wydrukowano w I schemacie melodycznym (VII modus) ${ }^{17}$, natomiast Vidi aquam (w okresie wielkanocnym) w VIII modus. Co prawda wskazano przeznaczenie obydwu antyfon: na pokropienie, ale - podobnie jak w Gotteslob - nie określono precyzyjnie miejsca ich wykonania w liturgii. Przemilczano w ten sposób obowiązujące przepisy posoborowe, które zmieniły miejsce obrzędu Aspersji. Przed Soborem Watykańskim II był on bowiem odprawiany przed liturgią mszalną, natomiast po Vaticanum II pokropienie wiernych wodą świeconą w czasie niedzielnej Mszy św. jest jedną z form aktu pokuty ${ }^{18}$.

Po przestudiowaniu stałych śpiewów mszalnych widać, że łączna zawartość ordinarium missae w porównaniu z Gotteslob jest stosunkowo skromna. Przede wszystkim śpiewnik ks. Siedleckiego nie uwzględnia żadnych dialogów i aklamacji mszalnych, aktu pokutnego, a nawet pomija śpiew Pater noster. Należy to uznać za ważny brak w ogólnej ocenie zamieszczonego repertuaru części stałych liturgii mszalnej. Podaje jedynie dwie formuły melodyczne rozesłania wiernych (Ite, missa est. Deo gratias, VIII i XI). W tym względzie zbiór niemiecki wypada zdecydowanie korzystniej, a nawet może stanowić wzór dla innych tego rodzaju edycji. Zawiera bowiem podstawowy kanon tekstów, będących pomocą dla wiernych uczestniczących w liturgii odprawianej w języku łacińskim: pozdrowienie wiernych, formułę aktu pokuty zakończoną Kyrie z Mszy XVI (Kyrie - Christe - Kyrie), Alleluia, dialog przed i po Ewangelii, aklamację do Modlitwy powszechnej (Te rogamus, audi nos), odpowiedź ludu Suscipiat Dominus..., dialog przed prefacją, aklamację po przeistoczeniu, konkluzję doksologii kończącej Modlitwę Eucharystyczną (Per omnia saecula saeculorum z odpowiedzią Amen), doksologię po embolizmie, wezwanie związane z obrzędem pokoju, odpowiedź na ukazanie postaci eucharystycznych (Domine, non sum dignus...) oraz pięć propozycji for-

${ }^{17}$ Graduale Romanum, Solesmis 1974, s. 707.

${ }^{18}$ K. Lisman, Repertuar gregoriański, s. 61. 
muł rozesłania wiernych (I, II, VIII, XIII, XVII). Poza tym Gotteslob nie tylko przedrukowuje dotychczasowe melodie mszalnych aklamacji łacińskich, ale poszerza je o kolejne dwie: Suscipiat Dominus i Domine, non sum dignus, które zamieszcza nowe typiczne wydanie Missale Romanum 2002 w wersji z 2008 roku $^{19}$.

\subsubsection{PROPRIUM MISSAE}

Drugą grupę śpiewów liturgii eucharystycznej stanowią części zmienne, proprium missae. Pod względem treściowym są one dostosowane do poszczególnych okresów roku liturgicznego, świąt i obchodów ${ }^{20}$. Należą do nich: introit, graduał, sekwencja, offertorium i communio. Śpiewnik kościelny ks. Jana Siedleckiego pod względem zawartości tego repertuaru w zestawieniu $\mathrm{z}$ edycją niemiecką ( 9 śpiewów ${ }^{21}$ ) wygląda również skromnie. Należą do nich śpiewy z mszy za zmarłych: introit - antyfona Requiem aeternam $\mathrm{z}$ wersetem Te decet hymnus i communio (najstarsza z części proprium missae ${ }^{22}$ ) - antyfona Lux aeterna $\mathrm{z}$ wersetami Requiem aeternam i Cum sanctis; wezwanie pokutne Parce Domine; pięć sekwencji Victime paschali laudes przeznaczona na Niedzielę Zmartwychwstania Pańskiego, Veni Sancte Spiritus na uroczystość Zesłania Ducha Świętego, Lauda Sion na uroczystość Najświętszego Ciała i Krwi Chrystusa, Dies irae i dodana Stabat Mater wykonywana we wspomnienie Najświętszej Maryi Panny Bolesnej (15 IX). Po Soborze Watykańskim II tylko dwie spośród wymienionych (Victime paschali laudes i Veni Sancte Spiritus) uznano za obowiązkowe, natomiast pozostałe można wykonywać ad libitum. Z kolei Dies irae przeniesiono do Liturgii Godzin jako fakultatywny hymn w ostatnim tygodniu roku liturgicznego. Należy również zaznaczyć, iż sekwencja Lauda Sion wydrukowana została tylko fragmentarycznie. Spośród 24 strof zamieszczono dwanaście pierwszych. $\mathrm{Z}$ tego typu praktyką, nawet jeszcze znaczniejszego okrojenia, mamy do czynienia także w wielu innych

19 Missale Romanum, Editio typica tertia 2002.

${ }^{20}$ K. Lisman, Repertuar gregoriański, s. 72.

${ }^{21}$ P. Wiśniewski, Repertuar gregoriański, s. 352.

22 J. McKinnon, Communio w: Die Musik in Geschichte und Gegenwart, L. Finscher (red.), Kassel 1994, t. 2, kol. 961-967. 
śpiewnikach posoborowych, w których wykorzystano tylko jej fragment zaczynający się od słów Ecce Panis (21 zwrotka) ${ }^{23}$. W badanym zbiorze znajduje się również śpiew Ave verum (ku czci Najświętszego Sakramentu), który ma formę sekwencji i tak też jest sklasyfikowany w Liber Usualis ${ }^{24}$, jednak nie należy on do sekwencji mszalnych.

Wydaje się, że wybierając praktycznie części proprium z mszy za zmarłych, redaktorzy zbioru zachowali przedsoborowy status quo, kiedy to jedną z najczęściej odprawianych mszy było Requiem ${ }^{25}$. W analogiczny sposób postąpiono w edycji niemieckiej. Śpiewnik kościelny ks. Siedleckiego w porównaniu z wydawnictwem niemieckim znacznie korzystniej wypada pod względem repertuaru sekwencyjnego. Gotteslob zamieszcza jedynie dwie z nich (na Wielkanoc i na Zesłanie Ducha Świętego), eksponując $\mathrm{w}$ ten sposób okres wielkanocny i jego najwyższą rangę w roku liturgicznym. Natomiast zbiór Siedleckiego stara się wyraźnie podtrzymać wielowiekową tradycję kultywowania śpiewów sekwencyjnych, ocalając je nie tylko przed zapomnieniem, ale ukazując także zróżnicowane bogactwo tradycji muzycznej Kościoła.

Spośród śpiewów związanych ze sprawowaniem sakramentów w Śpiewniku kościelnym znajdujemy, identycznie jak w Gotteslob, tylko hymn Veni Creator Spiritus, z tą jednak różnicą, iż edycja polska drukuje wszystkie siedem strof, natomiast niemiecka pomija $\mathrm{z}$ niewyjaśnionych powodów ostatnią $\mathrm{z}$ nich.

\section{2. ŚPIEWY LITURGII GODZIN}

Gdy chodzi o śpiewy brewiarzowe, interesujący nas śpiewnik zawiera jedynie wybrane, pojedyncze antyfony, psalmy i hymny officium

${ }^{23}$ K. Lisman, Repertuar gregoriański w polskich śpiewnikach katolickich wydanych po Soborze Watykańskim II, w: W. Hudek (red.), Muzyka liturgiczna w Kościele katowickim 1925-2005, Katowice 2005, s. 164.

${ }^{24}$ Liber Usualis, s. 1856.

${ }_{25}$ Requiem było najczęstszą recytowaną mszą w średniowieczu, sprawowaną codziennie za zmarłych dobroczyńców, członków wspólnoty i podczas pogrzebów. W swej łacińskiej formie msza za zmarłych pozostała na przestrzeni stuleci zasadniczo niezmieniona, zob. J. Harper, Formy $i$ układ liturgii zachodniej od X do XVIII wieku, Kraków 2002, s. 143-144. 
divinum. $\mathrm{Z}$ pojedynczych antyfon wydrukowano: Ecce Dominus veniet (trzecia antyfona Nieszporów I Niedzieli Adwentu ${ }^{26}$ ); Ave Maria, gratia plena (na okres Wielkanocy i Wielkiego Postu), którą można wykonywać jako antyfonę do Magnificat lub także jako jedną z antyfon maryjnych na zakończenie Komplety ${ }^{27}$ oraz cztery antyfony maryjne, wykonywane na zakończenie Completorium ${ }^{28}$ : Alma Redemptoris Mater (wykonywana od I niedzieli Adwentu do Ofiarowania Pańskiego), Ave Regina caelorum (od Ofiarowania Pańskiego do Wielkiego Czwartku), Regina caeli (od Wigilii Paschalnej do soboty przed uroczystością Trójcy Świętej) i Salve Regina (od Trójcy Świętej do I niedzieli Adwentu). W liturgii posoborowej antyfony te można stosować ad libitum, tzn. bez wiązania ich z konkretnym okresem liturgicznym. Oznacza to, że można posługiwać się nimi zamiennie. Wyjątek stanowi jedynie Regina caeli, która związana jest z okresem wielkanocnym ${ }^{29}$. Spośród hymnów brewiarzowych umieszczonych w badanym zbiorze zamieszczono: Creator alme siderum (I Nieszpory Adwentu); Iesu, dulcis memoria (II Nieszpory Festum Sanctissimi Nominis Jesu); Ave, maris stella (Commune Festorum B. Mariae Virginis ${ }^{30}$ ) oraz Attende Domine et miserere. Najskromniej potraktowano psalmy, które reprezentuje jedynie Ps 50, Miserere mei Deus. Wydrukowano natomiast komplet tonów psalmowych, łącznie $\mathrm{z}$ Tonus peregrinus. W zestawieniu $\mathrm{z}$ wersją niemiecką znajdują się zarówno śpiewy wspólne dla obydwu edycji, jak i odrębne. Śpiewnik Siedleckiego pomija na przykład antyfony do kantyku Magnificat. Dla porównania Gotteslob podaje trzy: na okres zwykły Benedic, anima mea, Domino (Ps 103, VIIIa), na okres Narodzenia Pańskiego Natus est nobis hodie... (VIIIa); na okres Wielkanocy Venite et videte... (VIIIa) oraz samo Magnificat (VIII).

${ }^{26}$ Liber Usualis, s. 324.

27 Tamże.

${ }^{28}$ W Polsce antyfony te wykonywano zwyczajowo na zakończenie nieszporów, zob. K. Lisman, Repertuar gregoriański, s. 82.

29 Tamże.

${ }^{30}$ Liber Usualis, s. 1259-1260. 


\subsection{INNE OBRZĘDY}

Śpiewnik kościelny ks. Jana Siedleckiego zawiera także propozycje śpiewów wykonywanych w trakcie obrzędów związanych z rokiem liturgicznym oraz niezależnych od niego. Omówimy je w związku z tym nie w kolejności zaproponowanej przez redaktorów zbioru, ale w kolejności przyjętej przez Ogólne Normy Roku Liturgicznego i Kalendarza ${ }^{31}$. W posoborowym kalendarzu liturgicznym porządek okresów uwzględnia bowiem znaczenie poszczególnych etapów historii zbawienia, dlatego rozpoczyna się od Triduum Paschalnego, a następnie jest Okres Wielkanocny, Wielki Post, Okres Narodzenia Pańskiego, Adwent i Okres Zwykły ${ }^{32}$.

\subsubsection{TRIDUUM PASCHALNE}

Śpiewnik ks. Siedleckiego nie wyodrębnia Triduum Paschalnego, a utwory związane z liturgią tych dni zamieszcza częściowo w repertuarze wielkopostnym i wielkanocnym. Do takich należy antyfona Ubi caritas zarezerwowana na obrzęd przygotowania darów w liturgii Mszy Wieczerzy Pańskiej. Zbiór ks. Siedleckiego nie zaznacza w żaden sposób jej przeznaczenia jako śpiewu na offertorium w Wielki Czwartek. W porównaniu ze zbiorem niemieckim wydrukowano nie tylko samą antyfonę (Ubi caritas est vera, Deus ibi est), ale także trzy pierwsze zwrotki tej kompozycji. Pochwalić trzeba też redaktorów śpiewnika za wskazanie z imienia autora tego śpiewu, czego inne edycje na ogół nie czynią, zaznaczając jedynie, iż twórca tej kompozycji nie jest znany (Auctor ignotus in Italia, saec. $I X-X$ ?). Szkoda tylko, że imię kompozytora podane zostało z błędem. Jest nim nie „biskup Paulin z Akwilei”, jak wydrukowano, ale biskup Paolino z Akwilei (756-802), który skomponował ten hymn ok. 800 r. dla tamtejszej wspólnoty kościelnej ${ }^{33}$. Sekwencję Victime paschali laudes omówiono już wcześniej.

31 B. Nadolski, Liturgika, t. 2, Poznań 1991, s. 21-22.

${ }^{32}$ K. Lisman, Repertuar gregoriański, s. 85.

33 Autorstwo, czas i miejsce pochodzenia utworu udowodnił w niezbity sposób szwedzki naukowiec Dag Norberg, zob. P. Wiśniewski, Śpiewy mandatum w polskich drukach muzyczno-liturgicznych XVII wieku, Warszawa 2008, s. 75-76. 
Repertuar w zbiorze niemieckim podaje jeszcze antyfonę Ecce lignum crucis z odpowiedzią ludu Venite, adoremus ${ }^{34}$, przeznaczoną do wykonania podczas adoracji Krzyża w czasie liturgii Wielkiego Piątku oraz wezwanie Lumen Christi z odpowiedzią Deo gratias $^{35} \mathrm{z}$ Liturgii światła Wigilii Paschalnej.

\subsubsection{OKRES WIELKANOCNY}

$\mathrm{Na}$ czas Wielkanocy podano antyfonę Regina caeli laetare, alleluia ${ }^{36}$ i sekwencję Veni, Sanctae Spiritus na Uroczystość Zesłania Ducha Świętego. Wydrukowano co prawda jeszcze śpiew Alleluia. O filii et filiae, jednak należy on do grupy utworów pseudogregoriańskich.

\subsubsection{WIELKI POST}

Podany repertuar gregoriański tego okresu obejmuje cztery śpiewy: Attende Domine, psalm pokutny Miserere mei Deus i wezwanie Parce Domine. Redaktorzy w tym dziale uwzględnili także sekwencję Stabat Mater. Dla porównania śpiewnik Gotteslob nie zamieszcza, z wyjątkiem antyfony Ubi caritas (bez zwrotek) ${ }^{37}$, żadnego z pozostałych utworów.

\subsubsection{OKRES NARODZENIA PAŃSKIEGO}

Spośród podanych kompozycji w języku łacińskim jedynym śpiewem gregoriańskim, a faktycznie postgregoriańskim, jest Puer natus in

34 Gotteslob, Nördlingen 2013, n. 308.

35 Tamże, n. 312.

${ }^{36}$ Spośród wszystkich czterech antyfon maryjnych stosowanych w liturgii posoborowej: Alma Redemptoris Mater (od I niedzieli Adwentu do Ofiarowania Pańskiego), Ave Regina caelorum (od Ofiarowania Pańskiego do Wielkiego Czwartku), Regina caeli (od Wigilii Paschalnej do soboty przed uroczystością Trójcy Świętej) i Salve Regina (od Trójcy Świętej do I niedzieli Adwentu) jedynie Regina caeli związana jest z okresem wielkanocnym. Pozostałe można stosować ad libitum, tzn. bez wiązania ich z konkretnym czasem liturgicznym, P. Wiśniewski, Repertuar gregoriański, s. 356.

\footnotetext{
37 Gotteslob, n. 285.
} 
Bethlehem. Należy przypuszczać, iż redaktorzy śpiewnika nie wprowadzili innych utworów gregoriańskich na okres Narodzenia Pańskiego głównie ze względu na to, iż nie widzieli zapotrzebowania na tego typu kompozycje, ponieważ w tym okresie w polskich kościołach wykonuje się kolędy. Przykładem tego jest zamieszczony w zbiorze popularny XVIII-wieczny hymn łaciński Adeste fideles ${ }^{38}$, który drukuje także Gotteslob. Potwierdza to jednocześnie bardzo użytkowy charakter nowego wydania Śpiewnika kościelnego ks. Jana Siedleckiego, bez wyraźnej cezury na śpiewy gregoriańskie i pseudogregoriańskie.

\subsubsection{ADWENT}

Z licznych śpiewów gregoriańskich przeznaczonych na ten okres liturgiczny w nowym wydaniu śpiewnika ks. Siedleckiego odnotowujemy tylko dwa, omówione już przy okazji oficjum brewiarzowego: hymn Creator alme siderum i antyfonę Ecce Dominus veniet. $\mathrm{Z}$ kolei w miejsce gregoriańskiego introitu Rorate caeli zamieszczono jego pseudogregoriańską wersję powstałą we Francji w 1610 roku $^{39}$, chętnie powielaną także przez inne zbiory pieśni ${ }^{40}$. Drugim pseudogregirańskim śpiewem jest hymn Veni, veni emmanuel, oparty na siedmiu antyfonach nieszpornych (17-23 grudnia), z XV-wieczną melodią francuską.

\subsubsection{OKRES ZWYKKY}

Zbiór ks. Siedleckiego publikuje jedynie, z wyraźnym przeznaczeniem na obrzęd uwielbienia, hymn Te deum laudamus (w tonie solemnis), gdzie faktycznie znajduje się jego właściwe miejsce ${ }^{41}$. Szkoda jednak, że

${ }^{38}$ Nie notuje go ani Mszał, ani Brewiarz rzymski. Powstał w środowisku francuskim; jego autorem był prawdopodobnie John Francis Wade (1711-1786), nauczyciel łaciny i śpiewu kościelnego w Douai, zob. R. Rak, Adeste fideles, Encyklopedia Katolicka, t. 1, F. Gryglewicz i in. (red.), Lublin 1995, kol. 84.

39 A. Stingl Jun., Gregorianische Gesänge im Gotteslob 2013, s. 4, www.gregorund-taube.de (dostęp: 13.11.2014).

${ }^{40}$ K. Lisman, Repertuar gregoriański, s. 170.

${ }^{41}$ I. Pawlak, Muzyka liturgiczna, s. 349. 
nie podano także pozostałych śpiewów łacińskich z Graduale Simplex, z działu Pro gratis Deo reddendis, odpowiadających pojęciu cantica laudis: Te decet laus i Te laudamus, których teksty mają wyłącznie wielbiący charakter $^{42}$. Śpiewnik Gotteslob jest w tym względzie bardziej powściągliwy, zamieszczając co prawda Te Deum laudamus, ale bez sprecyzowania jego funkcji. Należy zaznaczyć, iż kompozycję tę można wykorzystać również przy innych okazjach.

Repertuar stricte gregoriański okresu zwykłego został potraktowany zatem marginalnie. Brakuje w nim śpiewów na wiele świąt Pańskich, których obchód liturgiczny przypada właśnie w tym okresie. Być może twórcom śpiewnika towarzyszyło przekonanie, iż o wiele chętniej wykonywane będą w tym czasie kompozycje w języku narodowym. Nie inaczej kwestia ta wygląda w Gotteslob, który obok Te Deum laudamus uwzględnia jeszcze święto Ofiarowania Pańskiego, na które podaje jedną $\mathrm{z}$ dwóch gregoriańskich antyfon, Lumen ad revelationem (druga to Exsurge Domine adjuva) $)^{43}$.

\subsection{SAKRAMENTALIA}

Omawiana edycja zamieszcza jeszcze dwie inne grupy śpiewów gregoriańskich. Do pierwszej z nich należy antyfona In paradisum, wykorzystywana w czasie obrzędu pogrzebu. Śpiew ten, obok Libera me Domine de morte oraz Subvenite Sancti Dei, był obowiązkowo wykonywany w przedsoborowej liturgii pogrzebowej. Natomiast po Soborze zrezygnowano z responsorium Libera me... ${ }^{44}$ Śpiewnik Siedleckiego zachowuje zatem jedną $\mathrm{z}$ dwóch przewidzianych kompozycji. Wybór antyfony In paradisum spowodowany został najprawdopodobniej jej popularnością. Identycznie postąpili w tym względzie redaktorzy Gotteslob.

Drugą grupę stanowią śpiewy ku czci Najświętszego Sakramentu. Zbiór ks. Siedleckiego zamieszcza następujące: antyfona Adoremus in aeternum; hymny Adoro te devote i $O$ salutaris Hostia oraz Tantum ergo Sacramentum, końcowy fragment Pange lingua, funkcjonujący samodziel-

\footnotetext{
${ }^{42}$ R. Adamko, Śpiewy uwielbienia, w: W. Hudek (red.), Muzyka liturgiczna, s. 150.

${ }^{43}$ Gotteslob, n. 264.1.

${ }^{44}$ Ordo cantus missae, Libreria Editrice Vaticana 1987, s. 146, 148.
} 
nie i wykonywany przed błogosławieństwem Najświętszym Sakramentem. $\mathrm{Z}$ kolei wydawnictwo niemieckie uwzględnia $\mathrm{z}$ tej grupy jedynie Tantum ergo Sacramentum, ale w całości z Pange lingua gloriosi ${ }^{45}$.

\section{PRÓBA OCENY}

W ogólnej ocenie repertuar śpiewów stricte gregoriańskich zawartych w Śpiewniku kościelnym ks. Jana Siedleckiego nie jest imponujący, zwłaszcza jeżeli rozłoży się go na poszczególne okresy liturgiczne, obchody i święta, niemniej jednak spełnia on bardzo ważną funkcję w formacji religijnej wiernych. Większość wydrukowanych utworów została bowiem przeznaczona wprost dla ludu jako pomoc w czynnym uczestniczeniu w liturgii sprawowanej w języku łacińskim. Zachowanie w nim pewnego kanonu śpiewów gregoriańskich, jako unitatis vinculum całego Kościoła, świadczy przede wszystkim o łączności z Kościołem Powszechnym, a nade wszystko umożliwia korzystanie z najbardziej podstawowego repertuaru gregoriańskiego podczas liturgii.

Jednoznaczna próba oceny omawianego śpiewnika nie jest jednak prosta. Wiele uroczystości zostało pominiętych, gdy chodzi o chorał gregoriański, a gros potraktowanych marginalnie. Porównując edycję polską z niemiecką, dostrzega się zarówno podobieństwa, jak i różnice. W zbiorze niemieckim na przykład wyeksponowano okres wielkanocny, zamieszczając wyłącznie dwie sekwencje: na jego rozpoczęcie i zakończenie. Podkreślono w ten sposób najwyższą jego rangę w roku liturgicznym. Nie można tego stwierdzenia odnieść bezpośrednio do Śpiewnika kościelnego ks. Siedleckiego, który podaje także sekwencje fakultatywne. Poza tym edycja polska podaje znacznie większy zasób utworów pseudogregoriańskich, opracowanych współcześnie (np. Anima Christi; Maria Regina mundi; Salve, Mater misericordiae i inne), co świadczy o typowo użytkowej funkcji zbioru. W porównaniu jednak z Gotteslob śpiewnik polski o wiele bardziej uwydatnia tzw. mocne okresy roku kościelnego, zamieszczając m.in. Attende Domine, Parce Domine itd. Na czas Adwentu wydrukowano w nim na przykład nie tylko pseudogregoriański śpiew Ro-

${ }^{45}$ Gotteslob, n. 494. 
rate caeli ${ }^{46}$, jak postąpiono w edycji niemieckiej, ale również gregoriańską kompozycję Creator alme siderum. Tego typu niuansów można wskazać znacznie więcej.

W ogólnej ocenie Śpiewnik kościelny ks. Jana Siedleckiego należy uznać za ważne i potrzebne wydawnictwo propagujące chorał gregoriański, zarówno w obszarze liturgii officium divinum, jak i liturgii mszalnej. Wybierając szereg najbardziej popularnych utworów gregoriańskich, twórcy śpiewnika mieli zapewne na uwadze nie tylko względy czysto duszpasterskie, choć te niewątpliwie wybijają się poprzez pokaźny repertuar pseudogregoriański, ale także normy kościelne wskazujące na to, iż śpiew ten przez całe wieki był używany i stawiany za wzór muzyki liturgicznej. Pomimo faktu wprowadzenia do liturgii języków narodowych wciąż zajmuje on pierwsze miejsce, stanowiąc nieprzerwane źródło nowych twórczych inspiracji. Potwierdza to tym samym fakt, iż śpiew ten jeszcze „nie umarł”, ale żyje i ciągle jest istotnym punktem odniesienia przy określaniu wartości liturgicznej nowych kompozycji sakralnych ${ }^{47}$. Wybór określonego kanonu śpiewów gregoriańskich i zamieszczenie ich w osobnym rozdziale zbioru sprawia wrażenie, że repertuar ten jest nieprzerwanie obecny w obrzędach liturgicznych i stoi na ich straży. Poza tym śpiew ten odgrywa doniosłą rolę kulturotwórczą. Przez długi czas gregoriański cantus firmus był podstawą tworzenia muzyki wielogłosowej, a obecnie współczesnej muzyki liturgicznej. Będąc śpiewem wzorcowym i elitarnym, stanowi nadal niezbędny i niezastąpiony element łączący wiernych różnych narodowości podczas celebracji liturgicznych. Z całym przekonaniem należy przeto stwierdzić, iż najnowsze wydanie Śpiewnika kościelnego ks. Jana Siedleckiego jest kontynuacją wielowiekowej tradycji i spuścizny muzycznej Kościoła, umiejętnie dostosowaną do przeobrażeń wprowadzonych po Soborze Watykańskim II.

${ }^{46}$ Powstał on w 1610 roku we Francji, Stingl Jun, Gregorianische Gesänge, s. 4.

47 P. Wiśniewski, Duchowość chorału gregoriańskiego, „Liturgia Sacra” 19(2013), n. 1 , s. 117. 
Streszczenie. W związku z wydaniem kolejnego już wydania Śpiewnika kościelnego ks. Jana Siedleckiego artykuł podejmuje próbę odpowiedzi na pytanie, w jakim stopniu dowartościowano w nim chorał gregoriański w świetle obowiązujących przepisów liturgicznych oraz na ile skorzystano ze skarbca muzyki gregoriańskiej w jego przygotowaniu. W tym celu przebadano zawarty w nim repertuar gregoriański, rozpatrując go pod kątem poszczególnych obchodów roku liturgicznego oraz porównując go z niemieckim śpiewnikiem Gotteslob z roku 2013. Wybór określonego kanonu śpiewów gregoriańskich i zamieszczenie ich w osobnym rozdziale polskiego zbioru sprawia wrażenie, iż repertuar ten jest kontynuacją wielowiekowej tradycji muzycznej Kościoła, umiejętnie dostosowaną do przeobrażeń wprowadzonych po Soborze Watykańskim II. Świadczy o łączności z Kościołem Powszechnym umożliwiając korzystanie z najbardziej podstawowego repertuaru gregoriańskiego podczas liturgii. Pomimo faktu wprowadzenia do liturgii języków narodowych wciąż zajmuje on pierwsze miejsce, stanowiąc nieprzerwane źródło nowych twórczych inspiracji.

Słowa kluczowe: chorał gregoriański; śpiewnik liturgiczny; liturgia; muzyka liturgiczna.

Summary. Latin monody in the XLI edition of The Church Song-book by the Rev. Jan Siedlecki. With respect to another edition of The Church Song-book by the Rev. Jan Siedlecki, the article aims to show how much the song-book values Gregorian chant in relation to the binding liturgical regulations and to what extent Gregorian music was used while preparing the song-book. With this end in view, the Gregorian repertoire included in the song-book was studied with reference to different celebrations of the liturgical year and by comparing it to the German song-book Gotteslob from the year 2013. The fact that a certain series of the Gregorian singing has been chosen and placed in a separate chapter of the Polish collection gives an impression that the repertoire is a continuation of a centuries-old musical tradition of the Church, adjusted to the changes introduced after The Second Vatican Council. It indicates the unity with the Catholic Church, making it possible to use the most basic Gregorian repertoire in the liturgy. In spite of the fact that national languages were introduced in the liturgy, this repertoire still plays a vital role, being a source of creativity and inspiration.

Key words: Gregorian chant; liturgical song-book; liturgy; liturgical music. 